\title{
Effects of nutrient enrichment and grazers on coral reefs: an experimental assessment
}

\author{
Bradley T. Furman ${ }^{1,2,3, *}$, Kenneth L. Heck Jr. ${ }^{1,2}$ \\ ${ }^{1}$ University of South Alabama, Marine Sciences Department, Mobile, Alabama 36688, USA \\ ${ }^{2}$ Dauphin Island Sea Lab, 101 Bienville Boulevard, Dauphin Island, Alabama 36528, USA \\ ${ }^{3}$ Present address: PBS\&J, 7406 Fullerton Street, Suite 350, Jacksonville, Florida 32256, USA
}

\begin{abstract}
Macroalgae have become pervasive elements on coral reefs throughout the Caribbean. Many studies have suggested that the loss of herbivore populations and coastal eutrophication are driving this increase in algal biomass, although competing processes have rarely been assessed concurrently. We tested the single and interactive effects of urchin Diadema antillarum grazing and nutrient enrichment on macroalgal community dynamics in the lower Florida Keys, USA. Three levels of urchin density $\left(0,2,5\right.$ ind. plot $\left.{ }^{-1}\right)$ and 2 levels of nutrient enrichment were controlled in a fully orthogonal field experiment using calcium carbonate tiles as experimental substrata. Changes in the percent cover of macroalgal functional groups were estimated using weekly photoquadrats. After a $78 \mathrm{~d}$ observation period, algal recruitment remained low and did not appear to have been related to urchin density. However, we observed a significant nutrient effect on the relative abundance of algal functional groups. We attribute this effect to an unanticipated interaction with fish grazing intensity and suggest that the impacts of fish grazing masked those of $D$. antillarum and drove algal succession towards a benthos of algal turfs and crustose coralline algae. We conclude that nutrient enrichment is an unlikely explanation for the algal overgrowth of coral reefs in the Florida Keys.
\end{abstract}

KEY WORDS: Coral reefs $\cdot$ Nutrients $\cdot$ Grazers $\cdot$ Macroalgae $\cdot$ Diadema antillarum

\section{INTRODUCTION}

Coral reefs are rapidly declining worldwide (Pandolfi et al. 2003). The degree to which this represents a geologically unique event is much debated (Aronson et al. 2002); yet, there is a growing consensus that anthropogenic influences are at least partly responsible for accelerating the rate of decline of such reefs (Lapointe 1997, McCook et al. 2001, Szmant 2002, Pandolfi et al. 2003).

For a system historically described as a matrix of stony corals interspersed with low-biomass, highturnover algal turfs (i.e. erect macroalgae $<2 \mathrm{~cm}$ in height) and crustose coralline algae (CCA), reef degradation has most often been marked by a sharp increase in both the abundance and diversity of more erect macroalgal forms, and the decrease of competing space occupiers (Lewis 1985, 1986, Edmunds \& Car- penter 2001). In the Caribbean, this has meant a dramatic reduction in live coral cover (Murdoch \& Aronson 1999, Aronson et al. 2002) and the widespread dominance of algae in the genera Dictyota, Laurencia, Lobophora, Jania, Sargassum, and Halimeda (Ogden et al. 1973, Sammarco et al. 1974, Lewis 1986, McCook 1999, Lirman \& Biber 2000). Similar shifts toward leathery and corticated algae typify reef decline worldwide and have sparked an active debate regarding whether or not these changes represent a 'phase shift' (Lapointe 1997, McCook 1999, Edmunds \& Carpenter 2001, McCook et al. 2001, Williams \& Polunin 2001) or an alternative stable state (Beisner et al. 2003).

The global increase in algal abundance does not appear to have a universal cause, as past studies have identified a host of stressors each thought to affect reef ecosystems. These include alterations in herbivore density, either through over-fishing (Hay 1984, 
Hughes et al. 1999) or mass mortality (de Ruyter van Steveninck \& Bak 1986, Liddell \& Ohlhorst 1986); eutrophication, either anthropogenically forced (Lapointe 1997, 1999, Lapointe et al. 2004a) or naturally cyclic (Leichter et al. 2003); coral diseases, including white and black band disease (Aronson et al. 2002); weather anomalies, including global warming, excessive cold fronts (Lidz \& Hallock 2000), and extensive hurricane activity (Hughes 1989); as well as sedimentation and riverine runoff events.

Despite the multitude of pathways leading to reef decline, the signs of an ailing reef system are invariably the same, i.e. the stepwise replacement of hard corals with increasingly dense stands of macroalgae (McCook et al. 2001, Szmant 2002). This process begins first with the opening of substrata via coral death, and ultimately leads to macroalgal recruitment under conditions of primary succession (McCook 1999, Aronson et al. 2002, Szmant 2002)

Efforts to identify the processes controlling algal recruitment have focused on 2 co-occurring processes: top-down control by herbivores (Ogden et al. 1973, Sammarco et al. 1974, Carpenter 1981, 1986, de Ruyter van Steveninck \& Bak 1986, Lewis 1986, Foster 1987, Edmunds \& Carpenter 2001, Williams \& Polunin 2001), and bottom-up control by both anthropogenic and natural nutrient inputs (Lapointe 1997, 1999, Hanisak \& Siemon 2000, Lidz \& Hallock 2000, Leichter et al. 2003).

Early controversy over the identity of the principal grazer (Hay 1981, 1984) has given way to strong lines of evidence supporting the dominant role of echinoid grazing in shallow reef habitats experiencing moderate surge (de Ruyter van Steveninck \& Bak 1986). In the Caribbean, grazing pressure has been primarily supplied by the black urchin Diadema antillarum (de Ruyter van Steveninck \& Bak 1986, Liddell \& Ohlhorst 1986). However, in regions of moderate coral cover, herbivorous fishes in the families Acanthuridae and Labridae (formerly Scaridae) appear capable of maintaining algal abundance at pre-decline levels (Hay 1981, 1984, Lewis 1985, 1986, Williams \& Polunin 2001, Diaz-Pulido \& McCook 2003).

In sharp contrast to the wealth of evidence documenting the primacy of top-down mechanisms, studies suggestive of bottom-up controls have, to date, yielded variable and less well-defined results (McCook 1999, Szmant 2002). Although macroalgae commonly exhibit positive relationships between growth and nutrient concentration, clear evidence for enhanced growth rate, lateral expansion, or enhanced fecundity under conditions of nutrient addition is lacking (Miller et al. 1999, Jiménez \& Cortés 2003, McClanahan et al. 2003, Diaz-Pulido \& McCook 2005). Despite this, some investigators maintain that it is eutrophication that is responsible for the prevalence of macroalgae on reefs (Lapointe 1997, 1999, Hanisak \& Siemon 2000, Lapointe et al. 2004a,b, Littler et al. 2006).

In the present study, we directly assessed the relative importance of top-down and bottom-up processes in controlling macroalgal recruitment within a subtropical coral reef system. Statistically independent, structurally similar artificial reefs were used to simulate virgin reef substrata under conditions of primary succession, without the confounding influences of algal-coral interaction. Delivery of ecologically relevant levels of both nutrient enrichment and grazing intensity by the black urchin Diadema antillarum were used to assess the relative importance of these factors on reef-associated macroalgae.

\section{MATERIALS AND METHODS}

Study site. This study was conducted during the summer of 2004 in the Florida Keys National Marine Sanctuary at a shallow (2 m) low-relief, hard-bottom region adjacent to the inshore patch reefs of the Newfound Harbor Sanctuary Preservation Area (SPA), a 'no-take' reserve $\left(24^{\circ} 37.075^{\prime} \mathrm{N}, 81^{\circ} 23.369^{\prime} \mathrm{W}\right)$. Here, the benthic community was generally sparse, with mixed assemblages of macroalgae (e.g. the genera Caulerpa, Laurencia, Acanthophora, Halimeda, Sargassum, and Dictyota), octocorals and isolated patches of seagrass (for further details see Miller et al. 2000, Lapointe et al. 2004a). Prior to the present study, only 2 Diadema antillarum were observed, and small aggregations of juveniles from the families Labridae (predominantly the striped parrotfish Scarus iserti) and Haemulidae (grunts) were present. The most common adult fishes were grunts (family: Haemulidae) that utilized gorgonian patches as diurnal refugia. Our site placement actively targeted bare substrata and sought to reduce proximity to octocorals and seagrasses. Contact with macroalgae could not be completely avoided, but was generally restricted to Halimeda spp. and Dictyota spp. and was consistent among experimental units.

Based on topographic simplicity and distance from existing reefs, we assumed that ambient levels of fish grazing would be (1) negligible relative to urchin grazing and algal growth and (2) homogeneous across the experimental array. We further assumed that algae would not prove to be recruitment limited during the summer months of this investigation. Suppositions of these types are implicit in most, if not all, field manipulations and correlative studies of urchin grazing that have been done to date.

The experimental unit. Past studies have illustrated the importance of substrate type in determining algal 


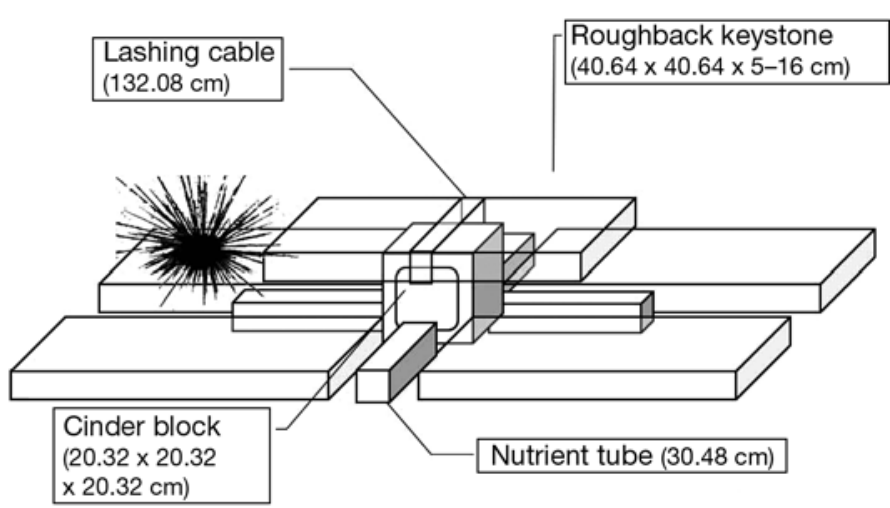

Fig. 1. Illustration of experimental unit showing the 5 symmetrically oriented tiles placed in each plot. Sea urchin shown (on left) for scale

recruitment (Diaz-Pulido \& McCook 2002) and limiting nutrient delivery to benthic communities (Brown et al. 2001). Therefore, we used rough-cut calcium carbonate (ancient coral) tiles, cut to standard rugosity on all sides except the top $(40.64 \times 40.64 \mathrm{~cm}$ and 5 to $16 \mathrm{~cm}$ in height). These 'roughback' tiles were quarried locally and replicated the skeletal substrate available to algal settlement following coral death (sclerites from ancient corals were readily visible on the surface of most tiles). All tiles were kept dry until deployment to prevent uneven colonization and biofilm development attributable to location and orientation of soaking (Kaehler \& Williams 1997).

Five symmetrically oriented tiles were placed in each plot (Fig. 1) with a cinder block forming a central podium upon which the fifth tile and all 4 nutrient delivery tubes $(6 \mathrm{~cm}$ diameter $\times 30 \mathrm{~cm}$ length with twenty $1 \mathrm{~cm}^{2}$ holes) were secured (for a further description of the PVC nutrient tubes see Heck et al. 2000). Eighteen plots were deployed on 10 June 2004 and interspersed in a randomized block design as described below, with a minimum segregation of $5 \mathrm{~m}$ between adjacent experimental units.

Treatment design. Experimental treatments followed a standard $2 \times 3$, fully orthogonal, factorial design with 2 levels of nutrient addition (enriched and ambient), 3 levels of herbivore density $\left(0,2,5\right.$ ind. $\left.\mathrm{m}^{-2}\right)$, and 3 replicates treatment ${ }^{-1}$.

Nutrient delivery was made following the general methods of Heck et al. (2000), with $500 \mathrm{~g}$ of the slowrelease commercial fertilizer Osmocote ${ }^{\mathrm{TM}}(\mathrm{N}: \mathrm{P}=8.3$ molar ratio) placed in each tube (i.e. $2 \mathrm{~kg} \mathrm{plot}^{-1}$ ). Osmocote $^{\mathrm{TM}}$ is the preferred nutrient source for coral reef nutrient enrichment experiments according to Littler et al. (2006). Tubes were replaced at approximately monthly intervals in accordance with published dissolution characteristics and ambient water temperatures (Heck et al. 2000).
Confirmation of nutrient delivery was made independently, through 2 established methods. First, to ensure that the loading rates were comparable among replicate plots, the remaining Osmocote ${ }^{\mathrm{TM}}$ in recovered tubes was dried to a constant weight and rates of loss ( $g$ tube $\mathrm{e}^{-1} \mathrm{~d}^{-1}$ ) were used to compare nutrient delivery among treatments. Second, to verify the accessibility of this fertilizer to macrophytes growing at the sediment-water interface, samples of macroalgae were analyzed for nutrient content (carbon:nitrogen:phosphorus, C:N:P). After 2 mo of nutrient additions, adult thalli of 2 consistently abundant macroalgal genera (Dictyota and Halimeda) were harvested from within $10 \mathrm{~cm}$ of the bottom, from 4 tiles of each experimental unit (8 August). One to 4 of these thalli were then subsampled, scraped for epiphytic algae, and dried at $60^{\circ} \mathrm{C}$ for $>72 \mathrm{~h}$. Resultant samples were ground to a fine homogeneous powder with a mortar and pestle and analyzed using a Costech C:N:S Auto-Analyzer for $\mathrm{C}: \mathrm{N}$, and a Skalar $\mathrm{San}^{+}$Auto-Analyzer for C:P.

Urchin densities were chosen to encompass the range reported for Diadema antillarum in the Florida Keys prior to their mass mortality in 1983 (Bauer 1980). All urchins were hand-collected from the south side of Little Bahia Honda Island (located $0.8 \mathrm{~km}$ southwest of Bahia Honda Key within the Bahia Honda State Park) and transported to the study site during a $2 \mathrm{~d}$ period beginning on 12 June. Prior to deployment, horizontal test (oral hemisphere) diameters were measured using a caliper (mean $\pm \mathrm{SE}: 68.8 \pm 1.3 \mathrm{~mm}$ ). To ensure that treatment densities were maintained, subsequent validations were made throughout the course of the experiment at 48 to $72 \mathrm{~h}$ intervals, with all emigrants returned to appropriate treatments.

Hurricane disturbance. On 13 and 14 August 2004, a Category 2 hurricane (Charley) tracked close enough to Florida to bring tropical storm force conditions to the experimental array. Minor damages were recorded a day later. They included moderate tile movement, a loss of 13 urchins (31\%; no sign of direct mortality), and a detachment of 55 PVC tubes $(76 \%$; most were recoverable). A secondary set of urchins (13 ind.) was then collected from Little Bahia Honda Island on 19 August (mean \pm SE: $68 \pm 1.8 \mathrm{~mm}$ ) and a full complement of tubes, with a complete replacement of Osmocote $^{\mathrm{TM}}$ was in place by 20 August. Due to the minimal duration and magnitude of this disturbance to the integrity of the experiment, no further consideration was made of its effects on benthic succession. Consequently, all data were analyzed as being continuous throughout the $78 \mathrm{~d}$ manipulation (concluding 29 August 2004).

Benthic cover. Changes in the percent cover of major macroalgal functional groups, and other space occupiers, were directly assessed using successive 
photoquadrats. Functional groups included brown frondose algae (e.g. Dictyota spp.), red frondose algae (e.g. Laurencia spp.), crustose coralline algae (CCA), red calcareous algae, turf algal cyanobacteria/diatoms, and macroscopically bare space (following those of Miller et al. 2000). Photographs were taken weekly at each tile using an Olympus Stylus 400 digital camera set to its highest resolution and steadied for parallax error with a PVC-constructed tripod. Subsequent calculation of aerial cover was achieved through 2 separate methodologies to account for amorphous species boundaries.

The functional groupings of cyanobacteria/diatoms and algal turfs were evaluated using a modified randomized dot method with 25 dots tile ${ }^{-1}$ (i.e. 125 dots plot $^{-1}$ ). However, due to the orientation of certain upper tiles, portions of the bottom tiles occasionally became obscured. This resulted in some plots receiving fewer dots per tile than others. These deviations were slight and evenly distributed; therefore, the resulting percent covers were corrected for the number of dots actually falling within tile borders. All other functional groups were assessed using the area-calculating software Carnoy 2.1. Measurements from either method were made for each tile and then summed to give a plot total.

Fish grazing intensity. To evaluate our assumption that fish grazing would be negligible compared to urchin grazing, tethered leaves of Thalassia testudinum were used to assess the intensity of fish grazing. General methods followed those of Ogden et al. (1973) and, more recently, Goecker et al. (2005), with 2 leaves shoot ${ }^{-1}$ and 3 shoots attached to $0.5 \mathrm{~m}$ lengths of sisal rope. Tethers were anchored to a haphazardly chosen tile (bottom tiles only) at each plot for durations of $5 \mathrm{~h}$, then retrieved and re-scanned. The differences in pre- and post-deployment leaf area were then averaged by rope and interpreted as the percent $T$. testudinum consumed.

To determine the degree to which nutrient concentration influenced grazing intensity, 'high' nitrogen seagrass leaves were presented at enriched plots and 'low' nitrogen leaves at ambient plots. The high-nitrogen seagrass was collected from a residential boat canal in Big Pine Key, Florida (used by Goecker et al. 2005). Recent studies have shown this canal to be impacted by the sewage disposal systems common in that portion of the Florida Keys (Tomasko \& Lapointe 1991, Lapointe et al. 2004a). As a result, seagrass leaves from this canal consistently demonstrated higher nitrogen concentrations than did leaves from undeveloped sites $(2.14 \% \mathrm{~N}$ and $1.58 \% \mathrm{~N}$, respectively; Goecker et al. 2005). The low-nitrogen seagrass leaves were collected from a tidally influenced, highflow meadow immediately south of Little Palm Island (described in more detail by Goecker et al. 2005). Source beds remained consistent throughout the experiment to minimize variability. All seagrass leaves were collected, scanned, and tethered $<24 \mathrm{~h}$ prior to deployment. Nine assays were performed between 15 July and 26 August.

Fish community. To determine whether treatments influenced the abundance and composition of fish within the experimental array, visual fish counts were made. These were 'instantaneous' counts of all fishes above or within the experimental plots as observed from an initial distance of 2 to $3 \mathrm{~m}$ and then followed by a closer inspection for more cryptic species. All fishes enumerated in this manner were identified to the family level. Six assessments were made between 26 June and 23 August.

Statistical analysis. Two-way analysis of variance (ANOVA) was used to test for the main and interactive effects of nutrient enrichment and urchin density on the percent cover of dominant space occupiers and on the C:N and C:P ratios of harvested macroalgae. To eliminate issues of non-independence introduced by repeatedly sampling photoquadrats, only data from the final sampling date (Day 76) were included in the ANOVA. A 3-way interactive model (nutrient enrichment $\times$ urchin density $\times$ day) was used to compare fish grazing intensity. In all cases, transformations were made to satisfy the ANOVA assumptions prior to analysis. All univariate analysis was performed on Minitab 13.1.

Multivariate analysis of fish community data was performed using the PRIMER 5 software for analysis of similarities (ANOSIM) and similarity percentages (SIMPER). The multidimensional scaling (MDS) of plot composition and related community parameters among treatments were based on resemblance matrices of fourth-root transformed, Bray-Curtis similarities. 'Global' R statistics were assessed for significant treatment effects (nutrient enrichment $\times$ urchin density) at $p=0.05$, whereas pair-wise comparisons were interpreted using the value of $\mathrm{R}$ itself, due to the limitations of permutation analysis in constructing consistent distributions.

\section{RESULTS}

\section{Nutrient enrichment}

Due to hurricane activity in the closing days of the experiment, data from only 2 of the 3 mo of nutrient additions were recovered; respective soak times were 24 and 29 d. Estimates of nutrient loading rates (on a per tube basis) revealed no discernible trends based on either plot position (plot number; $F_{8,63}=0.57, \mathrm{p}=0.801$ ) 
or urchin density $\left(F_{2,69}=1.50, \mathrm{p}=0.231\right)$, indicating that bulk flow and temperature were uniform across the experimental array. The overall dissolution was $43.96 \%$ (24 d) and $49.58 \%$ (29 d) of the available fertilizer mass, giving a mean loading rate of $3.35 \mathrm{~g} \mathrm{~N} \mathrm{~m}^{-2}$ $\mathrm{d}^{-1}$ and $0.90 \mathrm{~g} \mathrm{P} \mathrm{m}^{-2} \mathrm{~d}^{-1}$. These results suggest that monthly nutrient exchanges were sufficient to maintain elevated nutrient concentrations throughout the experiment.

Analysis of $\mathrm{C}: \mathrm{N}$ and $\mathrm{C}: \mathrm{P}$ ratios of the dominant macroalgae adjacent to the experimental reefs did not detect significant grazer effects. However, there was a nearly universal effect of nutrient addition on both C:N and C:P ratios (Fig. 2). Dictyota sp. exhibited the largest increases in tissue concentration, with significant differences detected between enriched values $\left(15.85 \pm 0.70, \mathrm{C}: \mathrm{N}_{i} 304.72 \pm 27.51, \mathrm{C}: \mathrm{P}\right.$; hereafter mean $\pm \mathrm{SE})$ and ambient controls $(21.11 \pm 0.55, \mathrm{C}: \mathrm{N} ; 632.70 \pm$ 38.36, C:P) for both $\mathrm{C}: \mathrm{N}\left(F_{1,12}=48.15, \mathrm{p}<0.000\right)$ and $\mathrm{C}: \mathrm{P}\left(F_{1,12}=48.82, \mathrm{p}<0.000\right.$; Fig. $\left.2 \mathrm{~A}, \mathrm{~B}\right)$. Halimeda sp. showed a less pronounced enrichment effect, with significant differences for C:P ratios only $\left(F_{1,12}=17.35, \mathrm{p}=\right.$ 0.001); however, there was a slight trend towards enriched nitrogen with a C:N ratio of $14.89 \pm 0.87$, compared to the control value of $16.15 \pm 0.91$ (logtransformed, $F_{1,12}=1.05, \mathrm{p}=0.325$; Fig. $\left.2 \mathrm{C}, \mathrm{D}\right)$.

These values were largely consistent with those reported by Diaz-Pulido \& McCook (2003) for artificially enriched Sargassum fossifolium recruits and are well within the published $\mathrm{C}: \mathrm{N}: \mathrm{P}$ values for benthic
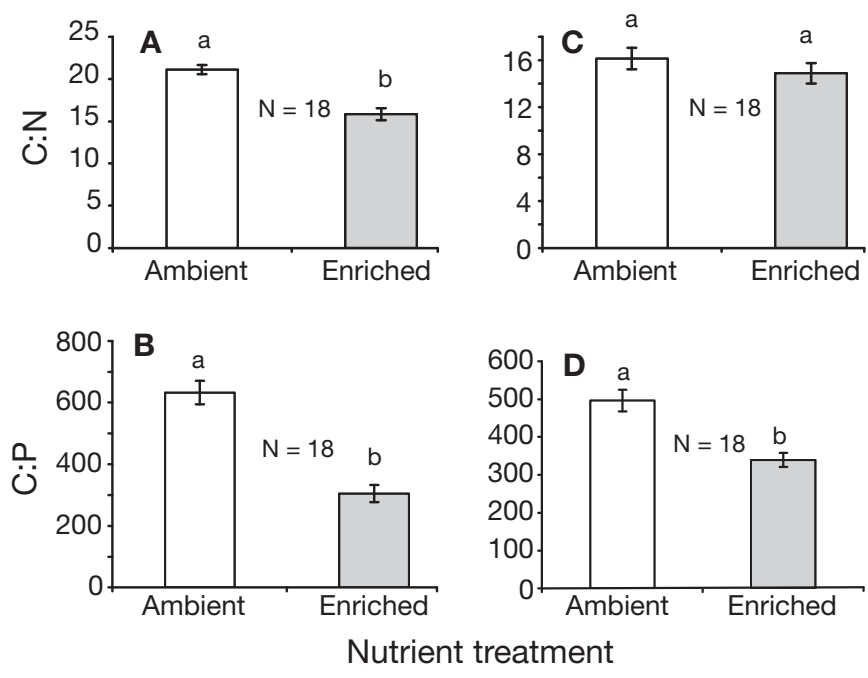

Fig. 2. Results from nutrient content analyses for $(\mathrm{A}, \mathrm{B})$ Dictyota antillarum and $(\mathrm{C}, \mathrm{D})$ Halimeda sp. Mean molar ratios $( \pm \mathrm{SE})$ of $(\mathrm{A}) \mathrm{C}: \mathrm{N}$ and $(\mathrm{B}) \mathrm{C}: \mathrm{P}$ were both significantly different in separate 2-way ANOVAs for Dictyota antillarum. Only C:P values were significantly different for Halimeda sp. (D; 2-way ANOVA). Different letters above bars denote a statistically significance difference at $\mathrm{p}<0.05$ macroalgae (Atkinson \& Smith 1983). This confirms that Osmocote ${ }^{\mathrm{TM}}$-derived nutrients were (1) available to the macroalgae associated with enriched plots and (2) not accessible to those of the ambient controls. It further supports the nutrient-limited status of reef algae for this region (Szmant \& Forrester 1996, Lapointe et al. 2004a) and supplies some evidence for possible phosphorus limitation in calcified chlorophytes.

\section{Sea urchin density}

Although issues of independence from nonrandom urchin replacement precluded parametric assessment, treatment densities, recorded every 48 to $72 \mathrm{~h}$, revealed clear differences, irrespective of nutrient treatment. The mean values for Diadema antillarum of $0.075,1.85$, and 4.42 ind. plot $^{-1}$ remained largely constant throughout the experiment, with the exception of the days around Hurricane Charley. The average deviation rate, by day, was approximately 0.05 urchins $\mathrm{d}^{-1}$ treatment density ${ }^{-1}$, with higher emigration noted from the higher density treatments. Such relationships are consistent with prior accounts of $D$. antillarum homing behavior (Carpenter 1984); however, the overall fidelity of these transplanted individuals was much greater than previously reported in attempts at repopulating patch reefs in this region (Miller et al. 2003).

Immigration to enriched zero-urchin plots was noted in the surveys, suggesting that urchin density can be influenced by local nutrient regimes. We interpret these minor trends in urchin movement as insignificant to the overall stability of the grazer treatment, and it remains clear that the experimental densities were (1) qualitatively different at every grazer level and (2) consistent throughout the observational time series.

\section{Benthic cover}

Despite an immersion period of nearly 3 mo with consistently elevated levels of nutrients, during the highest irradiance weeks of the year, no combination of frondose or erect calcareous macroalgae ever achieved an average percent cover $>0.04 \%$. CCA, turf, and cyanobacteria all accumulated much higher cover, but macroscopically bare substrata (sensu Johnson \& Brawley 1998) consistently dominated the surfaces of all experimental units.

Total macroalgae exhibited a later-stage recruitment event driven primarily by a pulse of red frondose algae (Laurencia sp.) to an enriched treatment of intermediate density. The degree to which this might have been a treatment effect is uncertain; however, its low 
Table 1. Results of 2-way ANOVA for the main and interactive effects of nutrient enrichment and urchin density on the percent cover of dominant space occupiers. All factors were 'fixed'. Boldface type indicates a significant probability of $\mathrm{p}<$ 0.05. Numerical footnote denotes methodology. CCA: crustose coralline algae

\begin{tabular}{|c|c|c|c|c|c|}
\hline Effect & $\mathrm{df}$ & SS & MS & $F$ & $\mathrm{p}$ \\
\hline \multicolumn{6}{|l|}{ Total macroalgae ${ }^{a}$} \\
\hline Nutrient & 1 & 0.001 & 0.001 & 0.009 & 0.926 \\
\hline Grazer & 2 & 0.017 & 0.009 & 0.134 & 0.876 \\
\hline Nutrient $\times$ Grazer & 2 & 0.150 & 0.075 & 1.174 & 0.342 \\
\hline Error & 12 & 0.769 & 0.064 & & \\
\hline Total & 17 & & & & \\
\hline \multicolumn{6}{|l|}{ Brown frondose $^{\mathrm{a}}$} \\
\hline Nutrient & 1 & 0.031 & 0.031 & 0.687 & 0.423 \\
\hline Grazer & 2 & 0.004 & 0.002 & 0.041 & 0.960 \\
\hline Nutrient $\times$ Grazer & 2 & 0.103 & 0.051 & 1.157 & 0.347 \\
\hline Error & 12 & 0.533 & 0.044 & & \\
\hline Total & 17 & & & & \\
\hline \multicolumn{6}{|l|}{ Red frondose $\mathrm{a}^{\mathrm{a}}$} \\
\hline Nutrient & 1 & 0.010 & 0.010 & 0.239 & 0.634 \\
\hline Grazer & 2 & 0.045 & 0.023 & 0.551 & 0.590 \\
\hline Nutrient $\times$ Grazer & 2 & 0.039 & 0.020 & 0.480 & 0.630 \\
\hline Error & 12 & 0.493 & 0.041 & & \\
\hline Total & 17 & & & & \\
\hline \multicolumn{6}{|l|}{$\mathbf{C C A}^{\mathrm{a}}$} \\
\hline Nutrient & 1 & 0.391 & 0.391 & 17.659 & 0.001 \\
\hline Grazer & 2 & 0.034 & 0.017 & 0.766 & 0.486 \\
\hline Nutrient $\times$ Grazer & 2 & 0.071 & 0.035 & 1.599 & 0.242 \\
\hline Error & 12 & 0.265 & 0.022 & & \\
\hline Total & 17 & & & & \\
\hline \multicolumn{6}{|c|}{ Red calcareous branching ${ }^{\mathrm{a}}$} \\
\hline Nutrient & 1 & 0.020 & 0.020 & 3.278 & 0.095 \\
\hline Grazer & 2 & 0.041 & 0.020 & 3.278 & 0.073 \\
\hline Nutrient $\times$ Grazer & 2 & 0.041 & 0.020 & 3.278 & 0.073 \\
\hline Error & 12 & 0.074 & 0.006 & & \\
\hline Total & 17 & & & & \\
\hline \multicolumn{6}{|l|}{ Calcifying algae ${ }^{a}$} \\
\hline Nutrient & 1 & 0.394 & 0.394 & 17.761 & 0.001 \\
\hline Grazer & 2 & 0.034 & 0.017 & 0.764 & 0.487 \\
\hline Nutrient $\times$ Grazer & 2 & 0.073 & 0.036 & 1.638 & 0.235 \\
\hline Error & 12 & 0.266 & 0.022 & & \\
\hline Total & 17 & & & & \\
\hline \multicolumn{6}{|c|}{ Non-calcifying algae ${ }^{a}$} \\
\hline Nutrient & 1 & 0.001 & 0.001 & 0.017 & 0.899 \\
\hline Grazer & 2 & 0.008 & 0.004 & 0.063 & 0.939 \\
\hline Nutrient $\times$ Grazer & 2 & 0.119 & 0.059 & 0.881 & 0.440 \\
\hline Error & 12 & 0.808 & 0.067 & & \\
\hline Total & 17 & & & & \\
\hline \multicolumn{6}{|c|}{ Macroscopically bare ${ }^{b}$} \\
\hline Nutrient & 1 & 0.262 & 0.262 & 42.308 & 0.000 \\
\hline Grazer & 2 & 0.029 & 0.014 & 2.309 & 0.142 \\
\hline Nutrient $\times$ Grazer & 2 & 0.024 & 0.012 & 1.933 & 0.187 \\
\hline Error & 12 & 0.074 & 0.006 & & \\
\hline Total & 17 & & & & \\
\hline \multicolumn{6}{|l|}{ Turf algae $^{b}$} \\
\hline Nutrient & 1 & 0.455 & 0.455 & 96.243 & 0.000 \\
\hline Grazer & 2 & 0.027 & 0.014 & 2.885 & 0.095 \\
\hline Nutrient $\times$ Grazer & 2 & 0.007 & 0.004 & 0.779 & 0.481 \\
\hline Error & 12 & 0.057 & 0.005 & & \\
\hline Total & 17 & & & & \\
\hline
\end{tabular}

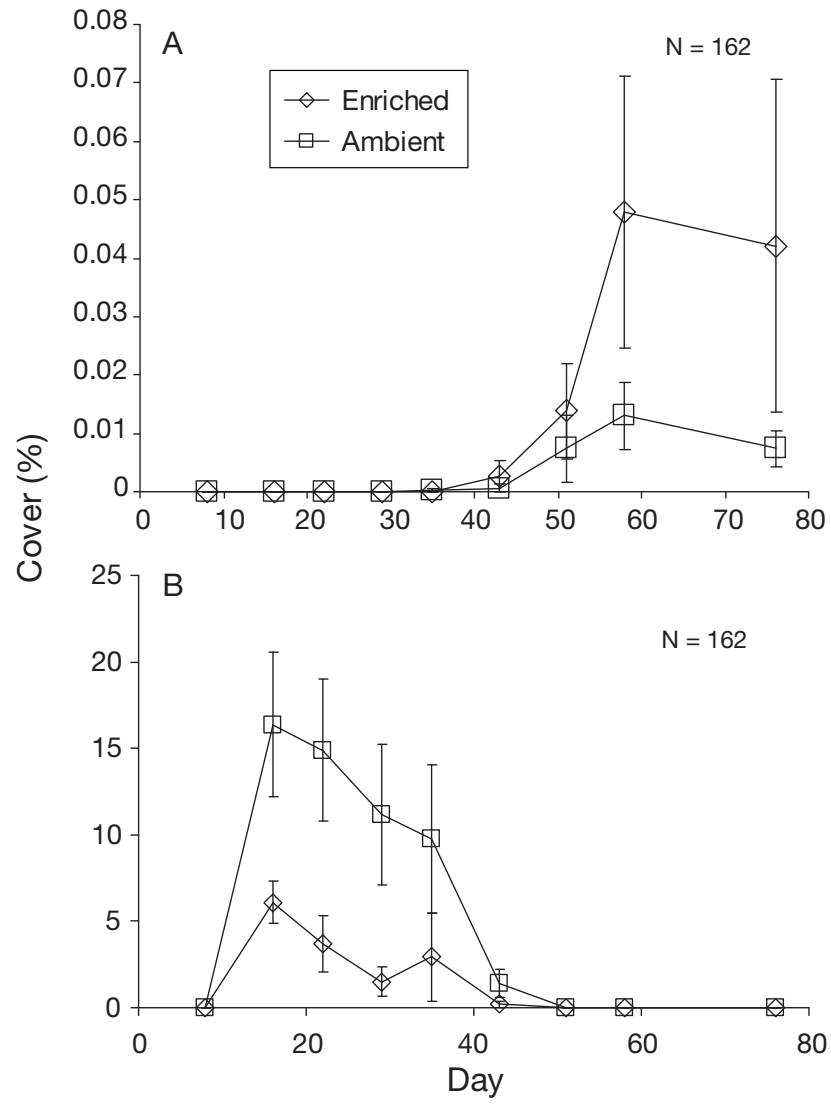

Fig. 3. Mean percent cover and standard errors of (A) total macroalgae and (B) cyanobacteria/diatoms, presented as a weekly time series by nutrient treatment

absolute value $(<<1 \%)$ indicates that it was probably more of an artifact than an ecologically relevant response. The effect of nutrient enrichment on total macroalgal cover was not significant $\left(F_{1,12}=0.009, \mathrm{p}=\right.$ 0.926 ; Table 1), although later stages of the time series indicate that this would have likely changed with increased duration, as enriched treatments accumulated qualitatively more macroalgae than ambient plots after Day 43 (Fig. 3A).

CCA was visible on most plots by Day 16 of the experiment, and CCA cover exhibited a strong positive effect of nutrient enrichment $\left(F_{1,12}=17.659, \mathrm{p}=0.001\right.$; Fig. 4A). Mean percent cover reached $0.284 \pm 0.059 \%$ in a near-linear fashion for the enriched treatments, while ambient controls tended to oscillate just above zero $(<0.02 \%)$.

Cyanobacteria and diatoms were the only components to show early-stage recruitment (Fig. 3B), but they had virtually been eliminated by Day 43 and were absent on the final sampling date. A 2-way ANOVA run on data from Day 16 did reveal a nutrient effect with significantly less cyanobacteria on nutrient-enriched plots $\left(F_{1,12}=5.165, \mathrm{p}=0.042\right)$. We interpret this effect cautiously, as negatively related to enrichment, a re- 


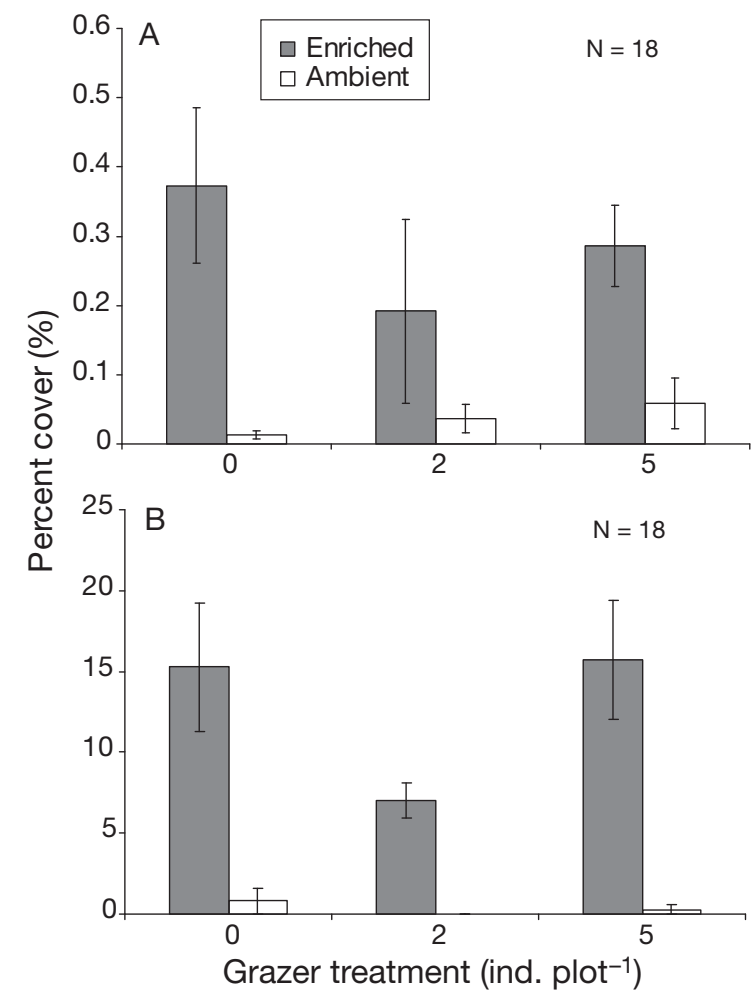

Fig. 4. Interaction plot of mean percent cover and standard errors for (A) crustose coralline algae and (B) turf algae. Nutrient effects for both functional groups were found to be significant in a 2-way ANOVA at $\mathrm{p}<0.05$

sponse commonly seen in enrichment studies of cyanobacteria, particularly those of nitrogen-fixing genera (Thacker \& Paul 2001, Clavier et al. 2005).

Turf algae exhibited a strong effect of nutrient enrichment $\left(F_{1,12}=96.243, \mathrm{p}<0.001\right.$; Table 1, Fig. 4B), with nearly 28 times more turf algae recorded on enriched plots. This trend remained consistent throughout the time course of the experiment.

The low values of benthic cover we observed call into question the issue of ecological versus statistical significance, an issue highlighted by the high degree of precision possible with digital techniques. These data have implications for recruitment comparisons and conflict with several of our original assumptions, namely, that algal propagules would be ubiquitous with little temporal variation during the June to August period and that small fish grazing would be both homogeneous at this scale of treatment segregation (i.e. $5 \mathrm{~m}$ ) and of a low absolute value relative to algal settlement and growth rates.

\section{Fish grazing intensity}

The 3-way ANOVA model on 4th-root transformed fish grazing intensity data (i.e. percent lost to grazing) revealed significant effects of both nutrients and day (nutrient, $F_{1,140}=34.19, \mathrm{p}<0.0001$; day, $F_{8,140}=9.57$, $\mathrm{p}=0.002$; Fig. 5). Subsequent comparisons revealed a consistent trend of enhanced piscine grazing at enriched plots. Although the design of these assays makes determining a precise mechanism difficult, since only enriched seagrass was presented at enriched plots and vice versa, past studies (Goecker et al. 2005) have demonstrated that enhanced seagrass consumption based on nitrogen condition alone exists within this system. What can be concluded is that grazing pressure on enriched seagrass was consistently and significantly greater than that of ambient seagrasses. Mean consumption was $35.02 \pm 0.14 \%$ for enriched and $21.38 \pm 0.15 \%$ (mean $\pm \mathrm{SE}$ ) for ambient grass (Fig. 5). These results indicate that fish grazing was enhanced by nutrient enrichment on scales smaller than or equal to the segregation of our experimental array.

\section{Fish community}

The 2-dimensional configuration of samples from MDS ordination of 4th-root transformed data for family-level fish abundances revealed a marginal pattern, with tighter clustering of enriched treatments (Fig. 6A). A 2-way crossed ANOSIM test confirmed
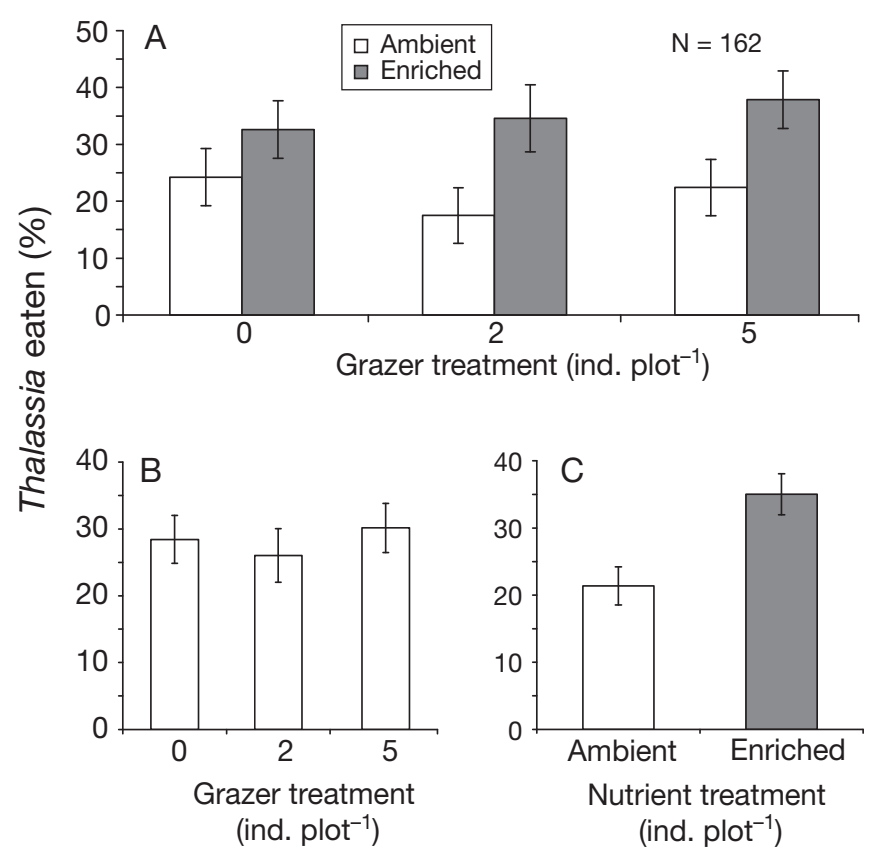

Fig. 5. Percent Thalassia testudinum consumed per assay, $5 \mathrm{~h}$ (mean \pm SE) presented as (A) an interaction plot and single factor plots of (B) grazer and (C) nutrient treatments. Only nutrient effects were found to be significant in a 3-way ANOVA at $p<0.05$ 
Fish community

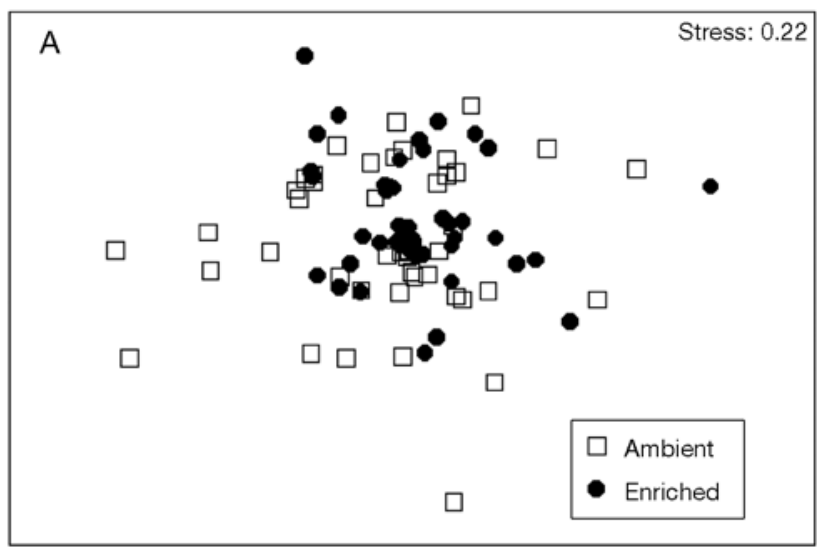

Fish community superimposed Scaridae abundance

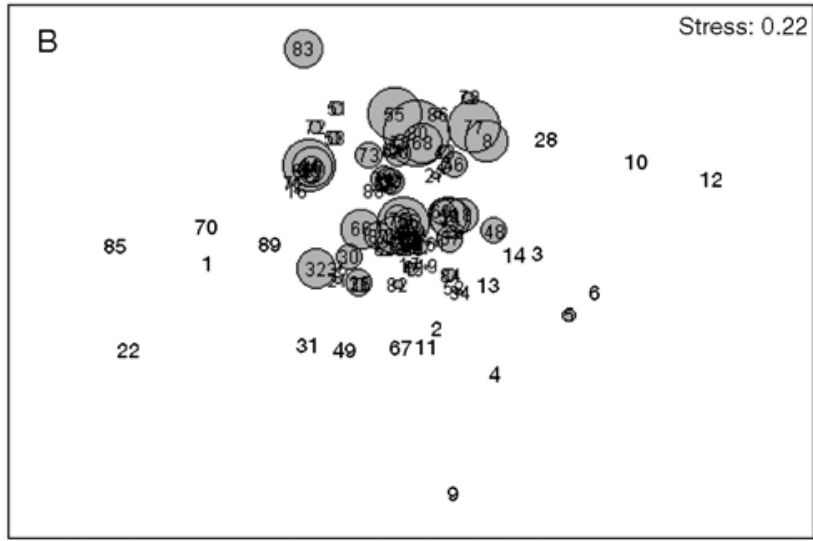

Fig. 6. MDS of family abundance observed above experimental units as quantified by initial count methods. Two-dimensional ordinations produced from 4th-root transformed, BrayCurtis similarity matrices are presented with samples delineated by (A) nutrient treatment and (B) superimposed with the dominant herbivore density (i.e. Scaridae) (stress $=0.22$

these differences based on nutrient treatment alone (ANOSIM, Bray-Curtis similarity, 4th-root transformed, nutrient 'global' $\mathrm{R}=0.046, \mathrm{p}=0.021$ ). Haemulidae $(37.13 \%)$ and Pomacentridae $(22.53 \%)$ explained most of the similarity within ambient controls, whereas Haemulidae $(29.72 \%$ ) and the herbivorous labrids (formerly Scaridae, $27.36 \%$ ) drove group cohesion among enriched plots (hereafter, SIMPER, 4th-root transformed, $90.00 \%$ cut-off). Overall group similarities were 62.09 and $70.70 \%$, respectively. This clustering of nutrient-enriched treatments gave rise to a $35.12 \%$ dissimilarity with ambient controls. The families Labridae (herbivorous taxa, 19.58\%; non-herbivorous taxa, $16.48 \%$ ) and Acanthuridae (14.18\%) explained the bulk of this mutual difference. This relationship is clearly seen in Fig. 6B, with a central clustering of enriched treatments based largely on the greater abundances of juvenile parrotfish.

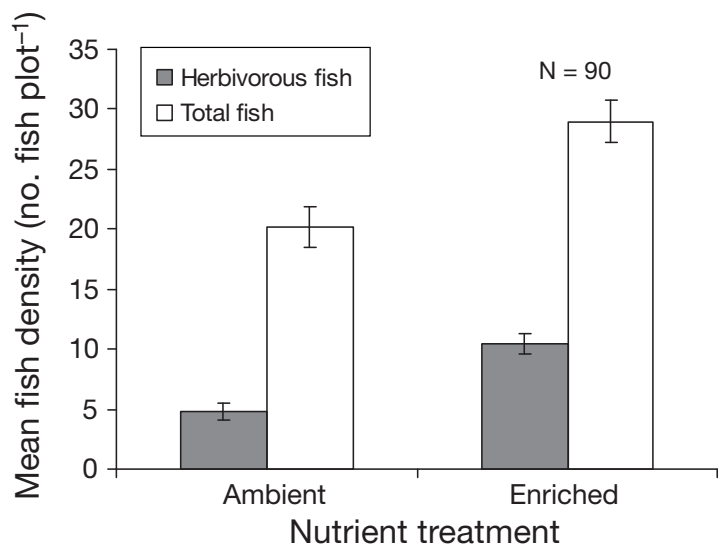

Fig. 7. Average herbivorous and total fish density (mean \pm SE) by nutrient treatment as quantified by initial count methods. Differences were statistically significant at $p<0.05$ (3-way ANOVA)

Results of the 3-way ANOVA confirmed higher densities of herbivorous fishes at the nutrient-enriched tiles, although this response varied with day (nutrient, $F_{1,76}=27.90, \mathrm{p}<0.0001 ;$ day, $F_{4,76}=3.04, \mathrm{p}=0.022$; Fig. 7). Similar effects were also found for total fish abundance (nutrient, $F_{1,76}=15.66, p<0.0001$; day, $F_{4,76}=7.39, \mathrm{p}<0.0001$; Fig. 7). These results indicate that localized nutrient addition precipitated a shortterm numerical increase in the surrounding fish community, with higher total fish abundances being driven largely by increases in the herbivorous labrids and acanthurids. This suggests that the direct effects of piscine grazing, as well as the indirect disturbances of invertivore feeding by juvenile haemulids, may have been more intense on the tile surfaces of enriched plots. Such heterogeneity within the spatial scale of the experimental array was unforeseen and directly conflicts with several of our a priori assumptions concerning background vertebrate grazing.

\section{DISCUSSION}

\section{Treatment maintenance}

Based on the estimated loading rates of recovered nutrients and the known dissolution characteristics of Osmocote $^{\mathrm{TM}}$ (Heck et al. 2000, Thacker et al. 2001, McClanahan et al. 2002), it appears certain that nitrogen and phosphorus levels were maintained well above ambient for the entirety of the manipulation. Results from algal tissue analysis confirmed the uptake of available forms (i.e. nitrate, ammonium, and phosphate) by 2 locally abundant algal genera. The fact that these algae were collected from the perimeter of our experimental units suggests that nutrient gradients 
not only encompassed the appropriate experimental units, but also dissipated prior to encroaching on nearby ambient controls.

Previous studies have reported difficulty in maintaining urchin densities in the field, with poor site fidelity often attributable to predator abundance or other density-related effects (Carpenter 1984, Miller et al. 2003). Common remedies have included caging (Carpenter 1986) and more invasive tethering techniques (McArdle 1993); however, in the absence of cages, and despite frequent inclement weather, we observed consistently stable adult Diadema antillarum densities in a topographically simple hard-bottom habitat. Results from near-continuous monitoring of urchin abundance showed that treatment densities were sustained throughout the experiment. Further evidence, such as the presence of fecal pellets on tile surfaces and the general lack of inter-plot grazing (i.e. halos or grazing shadows), suggests that not only did urchins remain present during the manipulation, but also that $D$. antillarum was directly interacting with the experimental substrata.

\section{Benthic succession}

Despite the sustained treatment levels, algal succession differed markedly from what we predicted. Several trends in algal recruitment emerged, all of which appeared to be the result of nutrient enrichment, and progressed irrespective of urchin density. For ambient treatments, we recorded a pronounced pulse in cyanobacteria and the development of dense diatomaceous mats. This occurred early in the time series, suggesting that biofilm development was rapid, even for virgin substrates. However, the later disappearance of cyanobacteria was unrelated to treatments or competition, as no competitor was seen to recruit to ambient tiles during the period of our observation. A similar lack of algal dominance was recorded for enriched treatments. Here again, we observed no effect of urchin grazing, with nutrient-enriched plots coming to support significantly higher coverage of both CCA and algal turf across all grazer treatments.

If strictly interpreted, these results are completely inconsistent with published models for both the role of nutrient enrichment (Lapointe 1997, 1999, Lapointe et al. 2004a,b) and the impact of urchin grazing, particularly that of Diadema antillarum (Carpenter 1981, 1986, Foster 1987, Edmunds \& Carpenter 2001). We observed no measurable macroalgal community development during time scales previously reported for similar experiments in coral reef environments (Lewis 1986, McClanahan et al. 2002, Diaz-Pulido \& McCook 2003, Lapointe et al. 2004b), and a benthos typical of healthy reef systems (i.e. CCA and algal turf) developed rapidly in treatments exposed to high rates of nutrification. To account for these unexpected results, we propose an explanation that questions the assumptions on which the study was originally based.

\section{Assumption-conclusion discrepancies}

Past investigators have asserted that algal propagules are ubiquitous in the water column and that algal recruitment patterns are not dictated by a lack of settlement (Lewis 1986). However, if propagule supply was limiting, what would its effect be on a standard factorial assessment such as ours? Would an experiment using percent cover as a metric of change retain the ability to distinguish general recruitment failure from intense grazing pressure? For a manipulation employing cages, the answer might be yes, where a lack of algal presence in caged treatments would indicate an absence of settlement. However, the direct influences of caging on propagule delivery (i.e. altered flow and epibiont fouling), as well their general inability to prevent meso- and micrograzer access, would confound any certainty in this regard. For an experiment such as ours, the answer is no; our ability to assign a causal mechanism to macroalgal absence is limited in situations where propagule supply is nonexistent, as competing alternative hypotheses quickly fail to become mutually exclusive. Does that imply that recruitment failure occurred for macroalgae of the lower Florida Keys in the summer of 2004? Not necessarily, although there is evidence of a periodicity in the delivery of propagules to the reef tract (i.e. synchrony of algal recruitment to the experimental array and its apparent correlation with meteorological data; Fig. 8).

It is generally hypothesized that a flow of comparatively eutrophied, frequently turbid, and occasionally sediment-laden, Florida Bay water often reaches the offshore reefs. This bay to ocean flow has been linked to meteorological events (Pitts 2001) and is often cited for influencing both the long-term distribution (Murdoch \& Aronson 1999) and the recent collapse of local coral communities (Lapointe et al. 2004a). Although terrestrial runoff includes both sediments and nutrients (Jiménez \& Cortés 2003), these bay water intrusions have mostly been discussed in terms of coastal eutrophication (Szmant \& Forrester 1996, but for an alternative viewpoint see Lapointe et al. 2004a). A much less investigated role may be that of propagule delivery from algal populations in nutrient-replete, herbivore-deficient waters. Lapointe et al. (2004a) concluded that northerly winds were a primary factor mediating nutrient delivery to resource-limited macroalgae in nearshore communities, ultimately linking 


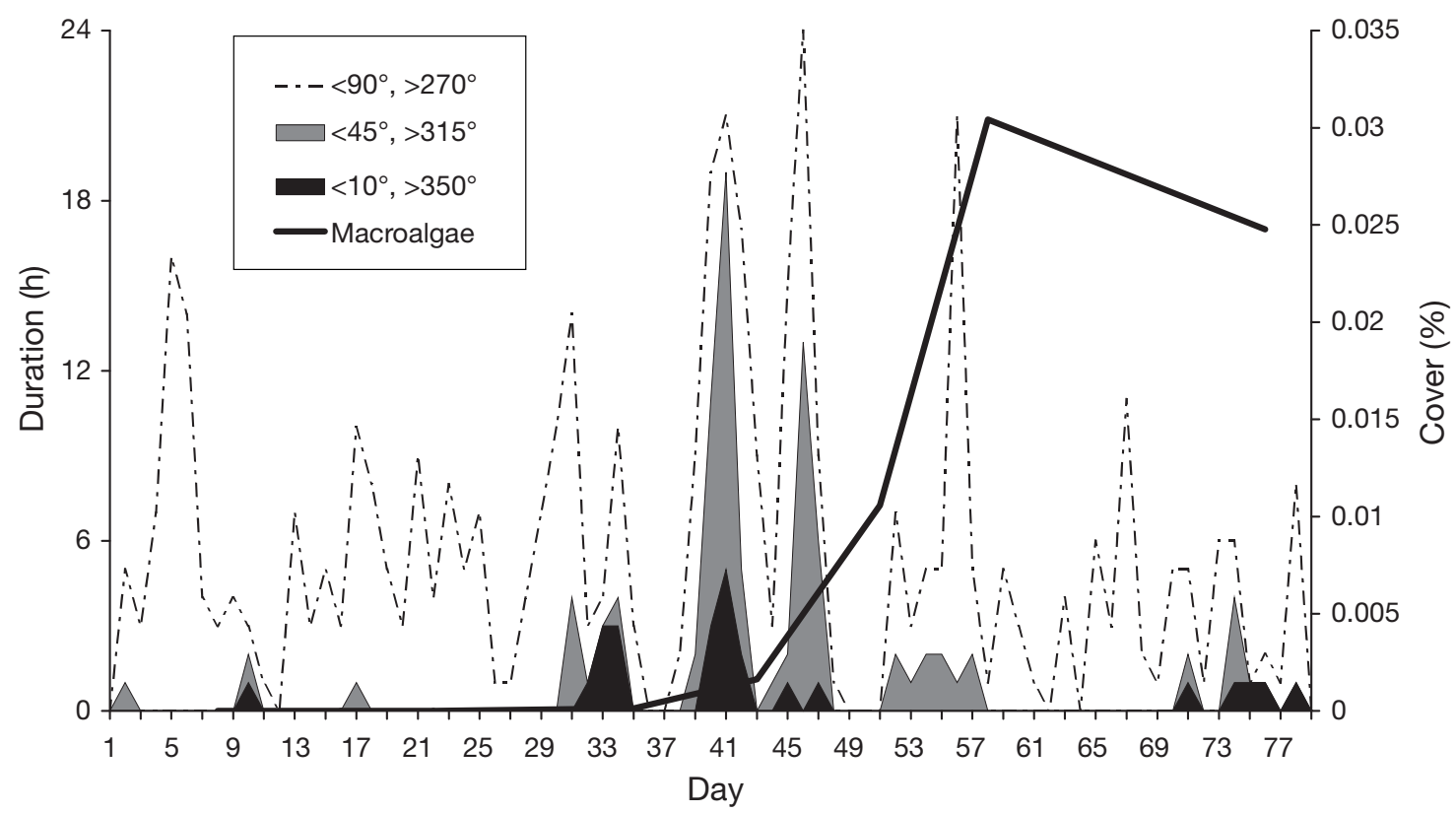

Fig. 8. Wind vector data from the National Data Buoy Center's SMKF1 Station (Sombrero Key, FL; 24 37' 36" N, 8106' 36" W). Peaks represent hourly average direction per day over the course of the experiment. Increasing color density indicates a more intense northerly component. Secondary $y$-axis data represent the percent cover of total macroalgae over the same time period

nutrient transport to enhanced benthic algal blooms. However, if this were so, we would have observed similar recruitment success throughout the summer, as experimentally derived nutrient conditions would have mimicked those of bay water intrusions. Alternatively, we recorded macroalgal growth at scales indicative of initial recruitment (thalli $<1 \%$ of tile surfaces) only after Day 42 of the experiment. It is interesting that this largely corresponded to the first intense wind event originating from the north (Fig. 8). It remains at least plausible then, given the complexity of macroalgal sexual reproduction (Luning \& tom Dieck 1989), that reef-associated macroalgae in the lower Florida Keys might function primarily as a recipient population, fed to some degree by propagules from Florida Bay and local canal systems. This was further corroborated by the failure of adult algae immediately adjacent (in all directions, at all scales) to the experimental array to demonstrate localized recruitment.

Although this may describe recruitment patterns for total macroalgae, it is insufficient to explain the succession at our nutrient-enriched treatments. Conventional wisdom suggests that early colonizers such as filamentous algal turfs and prostrate crusts should only persist under conditions of intense grazing. If true, their occurrence in all enriched treatments, regardless of urchin density, would have violated several of our assumptions regarding the primacy of urchin herbivory and the nature of juvenile fish grazing; several lines of evidence suggest that this may have been the case.

Prior to the experiment, we postulated that fish graz- ing would be low relative to echinoderm grazing, and essentially homogeneous across the spatial array. Under these assumptions, fish grazing should have had no significant effect on the single and interactive strengths of our main effects, and could have been used as a covariate to help explain any inter-site inconsistencies. The results of our fish counts and grazing assays both suggested that piscine grazing was the dominant disturbance in this system, a disturbance that was clearly based on nutrient treatment. Total fish abundance, as well as herbivore density, was consistently and significantly greater at enriched plots, and this numerical response, coupled with increased rates of consumption, indicates that fish herbivory was responsible for the arrested development of algal communities in enriched treatments and formed a buffer against algal invasions. The efficacy of this consumer control is likely mediated by several factors, including predation by larger fishes and environmental oscillations (i.e. storm activity and seasonality). However, as nutrient addition appears to stimulate grazing intensity and selectivity, it seems unlikely that eutrophication alone can play an appreciable role in algal accumulation.

\section{Implications of nutrient-mediated grazing}

The induction of grazing intensity through both numerical and functional feeding responses is a wellestablished consequence of both the nutrient content and general palatability of food resources (Bjorndal 
1980, Mattson 1980, Goecker et al. 2005), and has been shown to limit the biomass of certain primary producers even under conditions of intense eutrophication (Heck et al. 2000). However, the net effect of this selectivity in a system characterized by multispecies herbivore guilds and diverse floral communities remains poorly understood and largely overlooked.

The interplay between the species-specific rates of nutrient uptake, allocation and defensive strategies among macroalgae, and the varied abundance and identities of herbivores should combine to yield a lowstanding biomass of benthic algae, particularly for enriched macrophytes. By enhancing the energetic base of local herbivores and shifting production to more palatable forms, it seems doubtful that nutrient enrichment alone could produce algal dominance unless competitively advantaged species were universally defended against the full complement of grazers in a given area. However, defended taxa are not among those predicted by eutrophication models.

\section{CONCLUSIONS}

'The failure to detect a pattern is in itself a pattern' (Underwood et al. 2000). In this case, correlative lines of evidence pointed towards alternative mechanisms beyond those considered in the original design, namely, algal propagule availability and small vertebrate grazing. Given the small size of the principal grazers in this system, it is unlikely that caging experiments would have achieved the realism needed for a valid assessment under natural conditions. Similarly, we know of no reliable methodology to assess or quantify propagule densities of macroalgal species in situ. These limitations remain unresolved and are likely to have impacts on future investigations into the nature of algal communities on reefs.

Despite these deficiencies, this experiment adds to the growing body of literature identifying the pivotal role herbivory can play in controlling benthic primary production, particularly in the face of nutrification (Heck \& Valentine 2006). As currently assessed, nutrient enrichment does not appear to represent the primary cause of algal dominance on today's coral reefs (McCook 1999, Szmant 2002). The best evidence to the contrary often comes from localized extrema (e.g. intense point-source pollution) and is frequently confounded with concomitant factors or co-occurring processes that are rarely assessed (e.g. sediment load and reduced herbivore populations). Finally, we suggest that it is critical to better understand the properties and periodicities of sexually produced algal propagules, for, if a bottom-up signal does exist, this is where it will most likely be found. Acknowledgements. Thanks to Drs J. Valentine and M. Van- derklift for their valuable insight and advice during all stages of the project. Many thanks also to Dr. B. Rosov of the Nature Conservancy for much needed help in locating urchins. Many people deserve our thanks for their help in the field, including L. Kramer, C. Steeves, D. Byron, N. Geraldi, L. Chiaverano, M. Finnegan, R. Kroutil, and D. Blackman. Special thanks to C. Wood and others at the Dauphin Island Sea Lab and the University of South Alabama for technical and administrative support. All laboratory analyses were performed with the help of L. Linn. This project was conducted under generous financial and logistical support made available by grants from the National Undersea Research Center (NURC), the Nature Conservancy, the Dauphin Island Sea Lab (DISL), the University of South Alabama (USA), and the Alabama Center for Estuarine Studies (ACES). Dauphin Island Sea Lab Publication Number 391.

\section{LITERATURE CITED}

Aronson RB, Macintyre IG, Precht WF, Murdoch TJT, Wapnick CM (2002) The expanding scale of species turnover events on coral reefs in Belize. Ecol Monogr 72:233-249

Atkinson MJ, Smith SV (1983) C:N:P ratios of benthic marine plants. Limnol Oceanogr 28:568-574

Bauer JC (1980) Observations on geographical variations in population density of the echinoid Diadema antillarum within the western North Atlantic. Bull Mar Sci 30: 509-515

Beisner BE, Haydon DT, Cuddington K (2003) Alternative stable states in ecology. Front Ecol Environ 1:376-382

Bjorndal KA (1980) Nutrition and grazing behavior of the green turtle Chelonia mydas. Mar Biol 56:147-154

Brown GG, Maher WA, Norris RH, Matthieu J (2001) Problems with the use of terracotta clay saucers as phosphorusdiffusing substrata to assess nutrient limitation of epilithic algae. Freshw Biol 46:623-632

Carpenter RC (1981) Grazing by Diadema antillarum (Phillippi) and its effects on the benthic algal community. J Mar Res 39:749-765

Carpenter RC (1984) Predator and population density control of homing behavior in the Caribbean echinoid Diadema antillarum. Mar Biol 82:101-108

Carpenter RC (1986) Partitioning herbivory and its effects on coral reef algal communities. Ecol Monogr 56:345-363

Clavier J, Boucher G, Chauvaud L, Fichez R, Chifflet S (2005) Benthic responses to ammonium pulses in a tropical lagoon: implications for coastal environmental processes. J Exp Mar Biol Ecol 316:231-241

de Ruyter van Steveninck ED, Bak RPM (1986) Changes in abundance of coral-reef bottom components related to mass mortality of the sea urchin Diadema antillarum. Mar Ecol Prog Ser 34:87-94

> Diaz-Pulido G, McCook LJ (2002) The fate of bleached corals: patterns and dynamics of algal recruitment. Mar Ecol Prog Ser 232:115-128

> Diaz-Pulido G, McCook LJ (2003) Relative roles of herbivory and nutrients in the recruitment of coral-reef seaweeds. Ecology 84:2026-2033

Diaz-Pulido G, McCook LJ (2005) Effects of nutrient enhancement on the fecundity of a coral reef macroalga. J Exp Mar Biol Ecol 317:13-24

Edmunds PJ, Carpenter RC (2001) Recovery of Diadema antillarum reduces macroalgal cover and increases abundances of juvenile corals on a Caribbean reef. Proc Natl Acad Sci USA 98:5067-5071

Foster SA (1987) The relative impacts of grazing by 
Caribbean coral reef fishes and Diadema: effects of habitat and surge. J Exp Mar Biol Ecol 105:1-20

Goecker ME, Heck KL Jr, Valentine JF (2005) Effects of nitrogen concentrations in turtlegrass Thalassia testudinum on consumption by the bucktooth parrotfish Sparisoma radians. Mar Ecol Prog Ser 286:239-248

> Hanisak MD, Siemon LW (2000) Macroalgal tissue nutrients as indicators of nitrogen and phosphorus status in the Florida Keys. J Phycol 36:28

Hay ME (1981) Herbivory, algal distribution, and the maintenance of between-habitat diversity on a tropical fringing reef. Am Nat 118:520-540

Hay ME (1984) Patterns of fish and urchin grazing on Caribbean coral reefs: Are previous results typical? Ecology 65:446-454

> Heck KL Jr, Valentine JF (2006) Plant-herbivore interactions in seagrass meadows. J Exp Mar Biol Ecol 330:420-436

Heck KL Jr, Pennock JR, Valentine JF, Coen LD, Sklenar SA (2000) Effects of nutrient enrichment and small predator density on seagrass ecosystems: an experimental assessment. Limnol Oceanogr 45:1041-1057

Hughes TP (1989) Community structure and diversity of coral reefs: the role of history. Ecology 70:275-279

Hughes T, Szmant AM, Steneck R, Carpenter R, Miller S (1999) Algal blooms on coral reefs: What are the causes? Limnol Oceanogr 44:1583-1586

Jiménez C, Cortés J (2003) Growth of seven species of scleractinian corals in an upwelling environment of the eastern Pacific (Golfo de Papagayo, Costa Rica). Bull Mar Sci 72: 187-198

> Johnson LE, Brawley SH (1998) Dispersal and recruitment of a canopy-forming intertidal alga: the relative roles of propagule availability and post-settlement processes. Oecologia 117:517-526

Kaehler S, Williams GA (1997) Do factors influencing recruitment ultimately determine the distribution and abundance of encrusting algae on seasonal tropical shores? Mar Ecol Prog Ser 156:87-96

Lapointe BE (1997) Nutrient thresholds for bottom-up control of macroalgal blooms on coral reefs in Jamaica and southeast Florida. Limnol Oceanogr 42:1119-1131

Lapointe BE (1999) Simultaneous top-down and bottom-up forces control macroalgal blooms on coral reefs (reply to the comment by Hughes et al.). Limnol Oceanogr 44: 1586-1592

Lapointe BE, Barile PJ, Matzie WR (2004a) Anthropogenic nutrient enrichment of seagrass and coral reef communities in the lower Florida Keys: discrimination of local versus regional nitrogen sources. J Exp Mar Biol Ecol 308: 23-58

Lapointe BE, Barile PJ, Yentsch CS, Littler MM, Littler DS, Kakuk B (2004b) The relative importance of nutrient enrichment and herbivory on macroalgal communities near Norman's Pond Cay, Exumas Cays, Bahamas: a 'natural' enrichment experiment. J Exp Mar Biol Ecol 298: 275-301

Leichter JJ, Stewart HL, Miller SL (2003) Episodic nutrient transport to Florida coral reefs. Limnol Oceanogr 48: 1394-1407

> Lewis SM (1985) Herbivory on coral reefs: algal susceptibility to herbivorous fishes. Oecologia 65:370-375

> Lewis SM (1986) The role of herbivorous fishes in the organization of a Caribbean reef community. Ecol Monogr 56: $183-200$

Liddell WD, Ohlhorst SL (1986) Changes in benthic community composition following the mass mortality of Diadema at Jamaica. J Exp Mar Biol Ecol 95:271-278
Lidz BH, Hallock P (2000) Sedimentary petrology of a declining reef ecosystem, Florida reef tract (U.S.A.). J Coast Res 16:675-697

> Lirman D, Biber P (2000) Seasonal dynamics of macroalgal communities of the northern Florida reef tract. Bot Mar 43: 305-314

Littler MM, Littler DS, Brooks BL, LaPoint BE (2006) Nutrient manipulation methods for coral reef studies: a critical review and experimental field data. J Exp Mar Biol Ecol 336:242-253

Luning $\mathrm{K}$, tom Dieck I (1989) Environmental triggers in algal seasonality. Bot Mar 32:389-397

Mattson WJ (1980) Herbivory in relation to plant nitrogen content. Annu Rev Ecol Syst 11:119-161

McArdle DA (1993) The effect of grazing by the sea urchin Echinometra lucunter on the benthic algal community. Masters thesis, Florida Institute of Technology, Melbourne, FL

McClanahan TR, Cokos BA, Sala E (2002) Algal growth and species composition under experimental control of herbivory, phosphorus and coral abundance in Glover's Reef, Belize. Mar Pollut Bull 44:441-451

> McClanahan TR, Sala E, Stickels PA, Cokos BA, Baker AC, Starger CJ, Jones SH IV (2003) Interaction between nutrients and herbivory in controlling algal communities and coral condition on Glover's Reef, Belize. Mar Ecol Prog Ser 261:135-147

McCook LJ (1999) Macroalgae, nutrients and phase shifts on coral reefs: scientific issues and management consequences for the Great Barrier Reef. Coral Reefs 18:357-367

McCook LJ, Jompa J, Diaz-Pulido G (2001) Competition between corals and algae on coral reefs: a review of evidence and mechanisms. Coral Reefs 19:400-417

Miller MW, Hay ME, Miller SL, Malone D, Sotka EE, Szmant AM (1999) Effects of nutrients versus herbivores on reef algae: a new method for manipulating nutrients on coral reefs. Limnol Oceanogr 44:1847-1861

Miller SL, Swanson DW, Chiappone M (2000) Rapid assessment methods and rationale for ecological assessment and monitoring of hard-bottom communities in no-take zones of the Florida Keys National Marine Sanctuary: Level II zone monitoring methods manual for the Florida Keys National Marine Sanctuary. The National Undersea Research Center, Key Largo, FL

Miller MW, Szmant AM, Fogarty N, Fasano C, Capo T, Nedimyer K (2003) Experimental outplanting and transplanting of Diadema antillarum in the Florida Keys: predation is limiting population recovery. Center for Marine Research and NOAA's National Undersea Research Center, Key Largo, FL

Murdoch TJT, Aronson RB (1999) Scale-dependent spatial variability of coral assemblages along the Florida reef tract. Coral Reefs 18:341-351

Ogden JC, Brown RA, Salesky N (1973) Grazing by the echinoid Diadema antillarum Philippi: formation of halos around West Indian patch reefs. Science 182:715-717

Pandolfi JM, Bradbury RH, Sala E, Hughes TP and others (2003) Global trajectories of long-term decline of coral reef ecosystems. Science 301:955-958

Pitts PA (2001) Interactions between Florida Bay and Atlantic shelf waters in response to tropical storm Gordon. Estuar Coast Shelf Sci 52:225-235

Sammarco PW, Levington JS, Ogden JC (1974) Grazing and control of coral reef community structure by Diadema antillarum Philippi (Echinodermata: Echinoidea): a preliminary study. J Mar Res 32:47-53

Szmant AM (2002) Nutrient enrichment on coral reefs: Is 
it a major cause of coral reef decline? Estuaries 25: 743-766

Szmant AM, Forrester A (1996) Water column and sediment nitrogen and phosphorus distribution patterns in the Florida Keys, USA. Coral Reefs 15:21-41

Thacker RW, Paul VJ (2001) Are benthic cyanobacteria indicators of nutrient enrichment? Relationships between cyanobacterial abundance and environmental factors on the reef flats of Guam. Bull Mar Sci 69:497-508

Thacker RW, Ginsburg DW, Paul VJ (2001) Effects of herbivore exclusion and nutrient enrichment on coral reef macroalgae and cyanobacteria. Coral Reefs 19:318-329

Editorial responsibility: Otto Kinne,

Oldendorf/Luhe, Germany
Tomasko DA, Lapointe BE (1991) Productivity and biomass of Thalassia testudinum as related to water column nutrient availability and epiphyte levels: field observations and experimental studies. Mar Ecol Prog Ser 75:9-17

Underwood AJ, Chapman MG, Connell SD (2000) Observations in ecology: you can't make progress on processes without understanding the patterns. J Exp Mar Biol Ecol 250:97-115

Williams ID, Polunin NVC (2001) Large-scale associations between macroalgal cover and grazer biomass on middepth reefs in the Caribbean. Coral Reefs 19:358-366

Submitted: July 24, 2007; Accepted: February 5, 2008

Proofs received from author(s): June 30, 2008 